\title{
A Novel GABA Receptor Modulates Synaptic Transmission from Bipolar to Ganglion and Amacrine Cells in the Tiger Salamander Retina
}

\author{
Peter D. Lukasiewicz ${ }^{1}$ and Frank S. Werblin ${ }^{2}$ \\ 'Departments of Ophthalmology, and Anatomy and Neurobiology, Washington University, St. Louis, Missouri 63110 and \\ 2Division of Neurobiology, Department of Molecular and Cell Biology, University of California, Berkeley, California 94720
}

We investigated the mechanisms underlying the modulation of transmitter release from bipolar cells. Three currents, measured under whole-cell patch clamp in the tiger salamander retinal slice, were used to identify the sites of modulation and to establish their pharmacological profile. (1) A light-elicited inhibitory current was measured in bipolar cells that could be blocked by picrotoxin. This input probably arrives via GABAergic amacrine cells since there is high GABA sensitivity at the bipolar cell terminals and little GABA sensitivity at the dendrites. (2) Voltage-gated barium currents were elicited by depolarizing voltage ramps in bipolar cells. These currents most likely flowed through the calcium channels that are associated with transmitter release at the bipolar terminal. Bath-applied GABA suppressed the barium currents. (3) Puffs of potassium at bipolar dendrites depolarized bipolar cells and elicited an excitatory synaptic current measured in amacrine and ganglion cells. The excitatory synaptic currents, which reflect bipolar cell transmitter release, were also blocked by bath-applied GABA. For all three currents, the effects of GABA could be reversed by picrotoxin, but not by bicuculline or SR95531. The pharmacological profile of the receptors mediating GABA suppression of the barium currents and of excitatory synaptic transmission is characteristic of $\mathrm{GABA}_{\mathrm{c}}$ receptors (Cutting et al., 1991; Polenzani et al., 1991; Shimada et al., 1992). GABA receptors at bipolar terminals gate a chloride conductance, and most were found to have the pharmacological properties of $\mathrm{GABA}_{\mathrm{c}}$ receptors (Lukasiewicz et al., 1994). By contrast, the GABA receptors on ganglion cells have been found to be the $G A B A_{A}$ subtype (Lukasiewicz and Werblin, 1990; Lukasiewicz et al., 1994). These results suggest that GABA acts presynaptically at $\mathrm{GABA}_{c}$ receptors at the bipolar cell terminals. The $\mathrm{GABA}_{\mathrm{C}}$ receptors open chloride channels that can modulate the release of excitatory transmitter. In some experiments, bicuculline or SR95531 reversed a component of the GABA suppression of synaptic transmission. This indicates that

\footnotetext{
Received Jan. 25, 1993; revised Aug. 10, 1993; accepted Aug. 12, 1993.

We thank Drs. C. J. Dong and J. F. Muller for their helpful comments. This work was supported by NIH Grants EY00561 (F.S.W.), EY08922 (P.D.L.), Core Grant EY02687 (P.D.L.), and a Research to Prevent Blindness Miriam and Benedict Wolf Scholars Award (P.D.L.).

Correspondence should be addressed to Dr. Peter D. Lukasiewicz, Department of Ophthalmology, Washington University School of Medicine, St. Louis, MO 63110.

Copyright (C) 1994 Society for Neuroscience $0270-6474 / 94 / 141213-11 \$ 05.00 / 0$
}

$\mathrm{GABA}_{\mathrm{A}}$ receptors may also play a role in modulating transmission between bipolar and ganglion cells.

[Key words: GABA, synaptic transmission, bipolar cell, retina]

There is good evidence that bipolar cells receive GABAergic synaptic input at their terminals. Bipolar cells have the greatest sensitivity to GABA at their axon terminals (Maple and Werblin, 1986; Tachibana and Kaneko, 1987; Karschin and Wassle, 1990; Heidelberger and Matthews, 1991). This spatial sensitivity suggests that GABA is probably used as a feedback transmitter by certain classes of amacrine cells. Amacrine cells in tiger salamander (Werblin et al., 1988; Yang et al., 1991), goldfish (Marc et al., 1978; Yazulla et al., 1987), turtle (Hurd and Eldred, 1989; Muller et al., 1991), and cat (Chun and Wassle, 1989; Pourchn and Owczarzak, 1989; Hughes et al., 1991) have been shown to utilize GABA. Ultrastructural studies in cat and goldfish have shown that GABAergic amacrine cells make contacts with the terminals of both ON and OFF bipolar cells (Marc et al., 1978; Yazulla et al., 1987; Chun and Wassle, 1989; Pourcho and Owczarzak, 1989; Muller and Marc, 1990).

Several subtypes of GABA receptors have been found on bipolar cells in different species. GABA receptors on teleost fish and rat bipolar cells have been shown to be of the $\mathrm{GABA}_{\mathrm{A}}$ subtype (Tachibana and Kaneko, 1987; Karschin and Wassle, 1990; Heidelberger and Matthews, 1991). GABA ${ }_{B}$ receptors that modulate calcium channels were found on some salamander bipolar cells (Maguire et al., 1989a). Using isolated goldfish bipolar cells, Heidelberger and Matthews (1991) showed that $\mathrm{G} \Lambda \mathrm{B} \Lambda$ can modulate calcium influx into goldfish bipolar terminals by two different mechanisms. GABA can act at $\mathrm{GABA}_{\mathrm{A}}$ receptors to increase a chloride conductance that reduces the size of the calcium current. In addition, GABA can act at a non$\mathrm{GABA}_{\mathrm{B}}$, non-GABA $\mathrm{A}_{\mathrm{A}}$ receptor subtype to shift the activation range of the calcium channels to more positive potentials, reducing calcium influx into goldfish bipolar terminals. In salamander (Lukasiewicz et al., 1994) and in rat (Feigenspan et al., 1993) bipolar cells, a third subtype of GABA receptor has been identified. This GABA receptor gates a chloride channel, but has been shown to be relatively insensitive to both bicuculline and pentobarbital (Feigenspan et al., 1993; Lukasiewicz et al., 1994). GABA receptors with this pharmacological profile have been termed $\mathrm{GABA}_{\mathrm{C}}$ receptors (Johnston, 1986; Cutting et al., 1991; Polenzani et al., 1991; Shimada et al., 1992).

We used retinal slices to investigate the pharmacology of the 


\section{OFF Bipolar Cell}

Figure 1. Light-evoked synaptic inputs to an OFF bipolar cell. The time course of the light stimulus is indicated by the trace below the responses in this and the next two figures. Full-field light stimuli were used. $A$, Synaptic currents elicited by light when the cell was held at the indicated potentials. $B$, Currentvoltage relationship of the inhibitory synaptic input measured at light $\mathrm{ON}$ (open triangles) and light OFF (solid triangles). Both currents reverse polarity near $-60 \mathrm{mV}$, the calculated $E_{\mathrm{C}}$ was $-61 \mathrm{mV} . C$, Current-voltage relationships of the photoreceptor-mediated inputs at light ON (solid circles) and light OFF (open circles). Both inputs reverse polarity near $0 \mathrm{mV}$. The recording electrode was filled with the $\mathrm{CsSO}_{4} / \mathrm{CsCl}$ intracellular solution.
A.

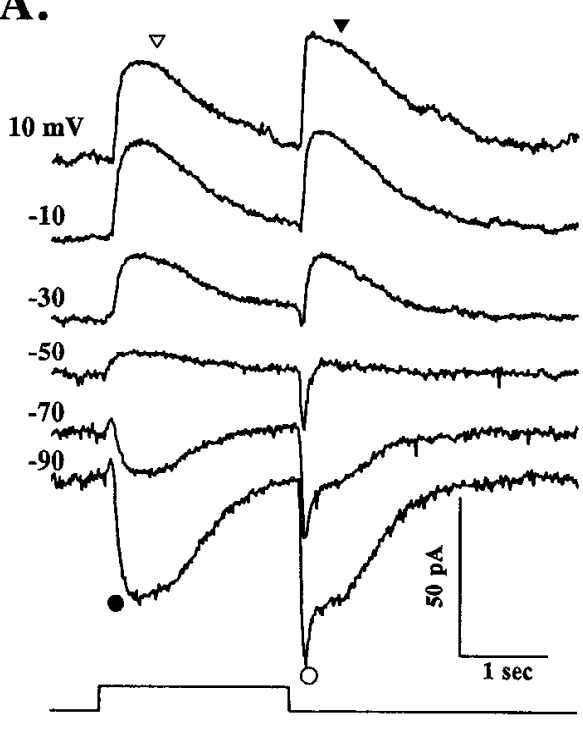

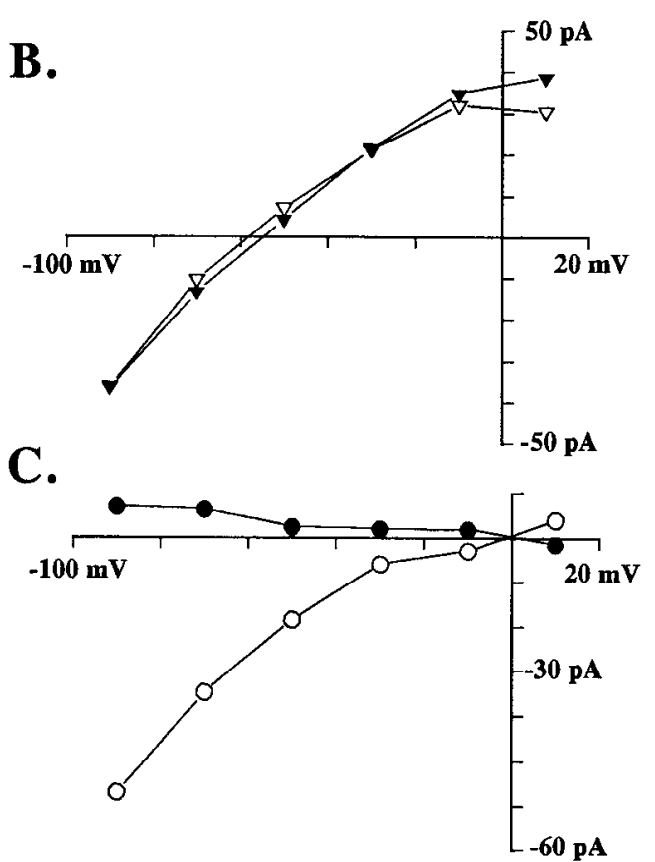

light-evoked inhibitory inputs to salamander bipolar cells. The inhibitory light responses were blocked by picrotoxin, but not by bicuculline or strychnine. This is similar to the pharmacology of GABA puff-evoked activity at bipolar terminals (Lukasiewicz et al., 1994), and suggests that the inhibitory inputs were at the bipolar terminals. We then determined if GABA could modulate synaptic transmission from bipolar cells to ganglion cells in a synaptically intact system. In the slice, we measured the effect of bath-applied GABA on bipolar cell barium currents and on synaptic transmission to cells postsynaptic to bipolar cells. GABA suppressed the barium currents that were most likely mediated by calcium channels located on the bipolar terminals (Maguire et al., 1989a; Heidelberger and Matthews, 1992). We also bioassayed bipolar terminal function by measuring the effects of GABA on excitatory transmission to both amacrine and ganglion cells. GABA blocked the excitatory inputs to these postsynaptic cells. For most cells, the suppression of the excitatory response was reversed by picrotoxin, but not by bicuculline or SR95531. Furthermore, the isomeric GABA analogs cis- and trans-aminocrotonic acid (CACA and TACA) also suppressed excitatory transmission to ganglion cells. The suppression by CACA or TACA was relatively insensitive to bicuculline in most cells. Our results suggest that under the conditions of our experiments GABA or CACA did not directly modulate the behavior of calcium channels. This is because when both $\mathrm{GABA}_{\mathrm{A}}$ and GA$\mathrm{BA}_{C}$ receptors were blocked by picrotoxin, GABA or CACA did not suppress excitatory transmission to ganglion cells. If GABA was acting at a receptor subtype that directly modulated calcium channel function (Maguire et al., 1989a; Heidelberger and Matthews, 1991), then transmitter release from bipolar cells should have been reduced in the presence of picrotoxin. These results suggest that $\mathrm{GABA}$, acting primarily at $\mathrm{GABA}_{C}$ receptors at bipolar terminals, open chloride channels that modulate the release of excitatory neurotransmitter. Although bicuculline and SR95531 were usually ineffective in reversing the GABA suppression of bipolar cell transmission, in some cells these antag- onists reversed a component of the suppression. This indicates that $\mathrm{GABA}_{\mathrm{A}}$ receptors can also modulate transmitter release in some bipolar cells.

\section{Materials and Methods}

Whole-cell patch recording in retinal slices. Whole-cell patch recordings (Hamill et al., 1981) were made from bipolar cells, amacrine cells, and ganglion cells in retinal slice preparations (Werblin, 1978). The recording and drug application procedures have been described in detail in the preceding article (Lukasiewicz et al., 1994). For light response experiments, dissections and slice preparations were performed in dim red light. Cells were patched onto under very dim illumination from a tungsten microscope illuminator. After a successful whole-cell recording was established, the preparation was dark adapted for at least $10 \mathrm{~min}$ before data were collected. All subsequent experimental manipulations were performed in the dark.

Puffing potassium at the bipolar dendrites. Synaptic responses in ganglion and amacrine cells were eliciled by "puffing" potassium chloride (KCl) $(120 \mathrm{~mm})$ through pipettes with $1 \mu \mathrm{M}$ diameter tips onto bipolar cell dendrites. The $\mathrm{K}^{+}$puffing solution was similar to the bathing solution, but equimolar $\mathrm{KCl}$ was substituted for sodium chloride $(\mathrm{NaCl})$. A Picospritzer (General Valve Corp., Fairfield, NJ) was used to puff $\mathrm{K}^{+}$ onto the dendrites (pressure, 5-20 psi). The puffer pipette tip was positioned $<10 \mu \mathrm{m}$ from the dendrites. The puff method and its calibration are described in detail in Lukasiewicz and Werblin (1990). In some earlier experiments, kainic acid was puffed onto bipolar dendrites to elicit synaptic responses in third-order cells. Kainic acid depolarized OFF bipolar cells, but not ON bipolar cells (Nawy and Jahr, 1990a). Therefore, in later experiments, potassium was used to elicit synaptic responses in both the ON and OFF pathways.

Electrode and bathing solutions. Our standard intracellular and extracellular solutions are described in Lukasiewicz et al. (1994). Modified solutions were used to measure the currents mediated by calcium channels in bipolar cells. For these experiments the bathing solution contained (in $\mathrm{mM}$ ) $\mathrm{NaCl}, 60$; tetraethylammonium, $40 ; \mathrm{KCl}, 2 ; \mathrm{BaCl}_{2}, 10$; $\mathrm{MgCl}_{2}, 1$; glucose, 5; and HEPES, 5, to enhance the amplitude of these currents. Intracellular solutions also contained $5 \mathrm{mM} \mathrm{Na}_{2}$ ATP and 0.5 mM Na-GTP [substituted for cesium fluoride (CsF)] to reduce rundown of the barium current.

Light stimulation. The light source was a tungsten halogen lamp ( 20 W) (Ealing Electro-Optics, Holliston, MA). The light was focused onto the preparation through the microscope objective via a light pipe that 


\section{OFF Bipolar Cell}
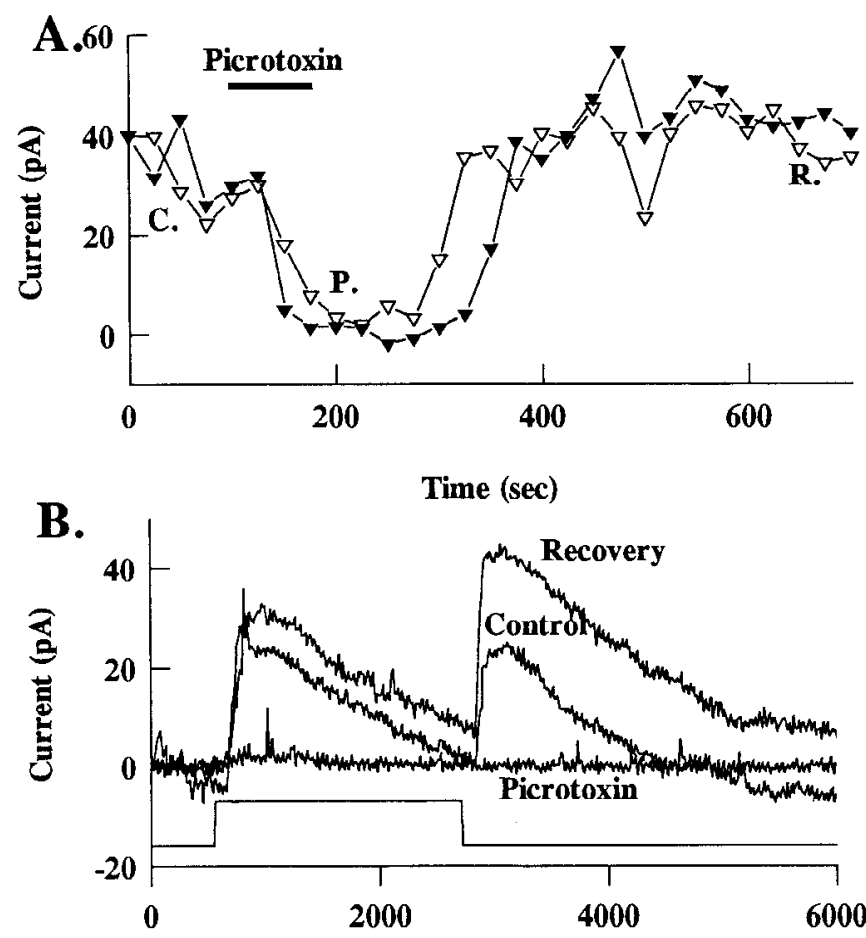

Time (msec)

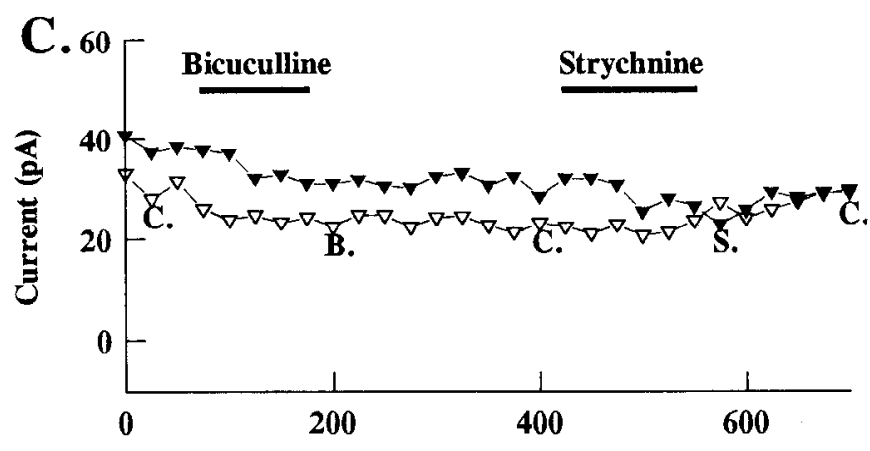

Time (sec)

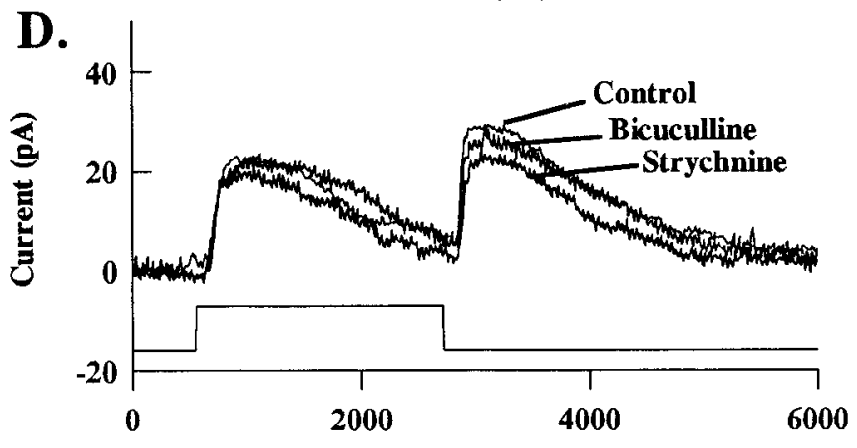

Time (msec)

Figure 2. Pharmacology of $O N$ and OFF light-evoked inhibitory synaptic inputs to an OFF bipolar cell. $A$, Peak amplitudes of ON and OFF synaptic responses plotted as a function of time. The $\mathrm{ON}$ responses are indicated by open triangles and the OFF responses are indicated by solid triangles. Picrotoxin reversibly depressed both the ON and the OFF inhibitory synaptic inputs. $B$, Individual inhibitory synaptic responses before, during, and after picrotoxin application. The control response was attached to the microscope head. Full-field light stimuli were used. A shutter controlled by a personal computer was placed in the light path and controlled the duration of the light stimuli. Neutral density filters were used to attenuate the intensity of the light stimulus.

\section{Results}

Light-evoked GABAergic synaptic transmission to bipolar cells The light-evoked synaptic currents recorded from an OFF bipolar cell are illustrated in Figure 1. A series of light-elicited currents recorded when the cell was held at the indicated potentials is shown in Figure $1 A$. The light-evoked currents recorded in OFF bipolar cells were composed of several components. $A$ slowly decaying current was elicited at both the onset (indicated by the open triangles) and the offset (indicated by the solid triangles) of the light stimulus. Both of these synaptic inputs reversed polarity between -70 and $-50 \mathrm{mV}$. The calculated chloride equilibrium potential was $-61 \mathrm{mV}$. This indicates that these inputs opened channels that were primarily permeable to chloride. Current measurements were made at the time points indicated by the open and solid triangles in Figure $1 A$. These measurements were used to construct the currentvoltage relationships for these two currents in Figure $1 B$. The slopes of the two current-voltage curves were linear over the range of potentials from -90 to $-10 \mathrm{mV}$. A small rectification occurred in both currents at potentials positive to $-10 \mathrm{mV}$. This indicates that the channels mediating the two slow inhibitory current responses were not voltage dependent over the physiologically relevant range of potentials.

A fast component of the synaptic current at light offset is shown in Figure $1 A$ (indicated by the open circle). This component of the light-evoked current reversed polarity at potentials more positive than the slow components of the response at light onset and light offset. The fast currents measured at light offset (at the time indicated by the open circle) were used to construct the current-voltage relationship (open circles) in Figure $1 C$. The fast component of the OFF response reversed polarity near 0 $\mathrm{mV}$. The fast current rectified at more negative potentials. The disproportionately larger current at negative potentials is probably due to contamination of the fast current by the slow inhibitory current. This fast current is the excitatory photoreceptor synaptic input received by OFF bipolar cells at light offset.

A small outward current component at light onset occurs at the time indicated by the solid circle in Figure $1 A$. The outward current reverses polarity at a potential more positive than the slow inhibitory current at light onset. Currents measured at the time indicated by the solid circle were used to construct the current-voltage relation (solid circles) in Figure $1 C$. The slope of the curve was linear and the current reversed polarity near $0 \mathrm{mV}$. The channels mediating this component of the light response were not voltage dependent. This current is the steady, inward current from photoreceptors that is turned off by light.

The pharmacology of the light-evoked inhibitory synaptic

is labeled $C$, the response in the presence of picrotoxin is labeled $P$, and the recovery response is labeled $R$ in $A$. $C$, Peak amplitudes of $\mathrm{ON}$ and OFF synaptic responses plotted versus time. Both bicuculline and strychnine did not have significant effects on the amplitudes of the ON or OFF inhibitory synaptic responses. $D$. Strychnine and bicuculline were relatively ineffective in reducing the amplitudes of the responses at light $\mathrm{ON}$ and light OFF. The control is the average of responses labeled $C$, the response in the presence of bicuculline is labeled $B$, and the response in the presence of strychnine is labeled $S$ in $C$. The recording electrode was filled with the $\mathrm{CsSO}_{4} / \mathrm{CsCl}$ intracellular solution. 


\section{ON Bipolar Cell}
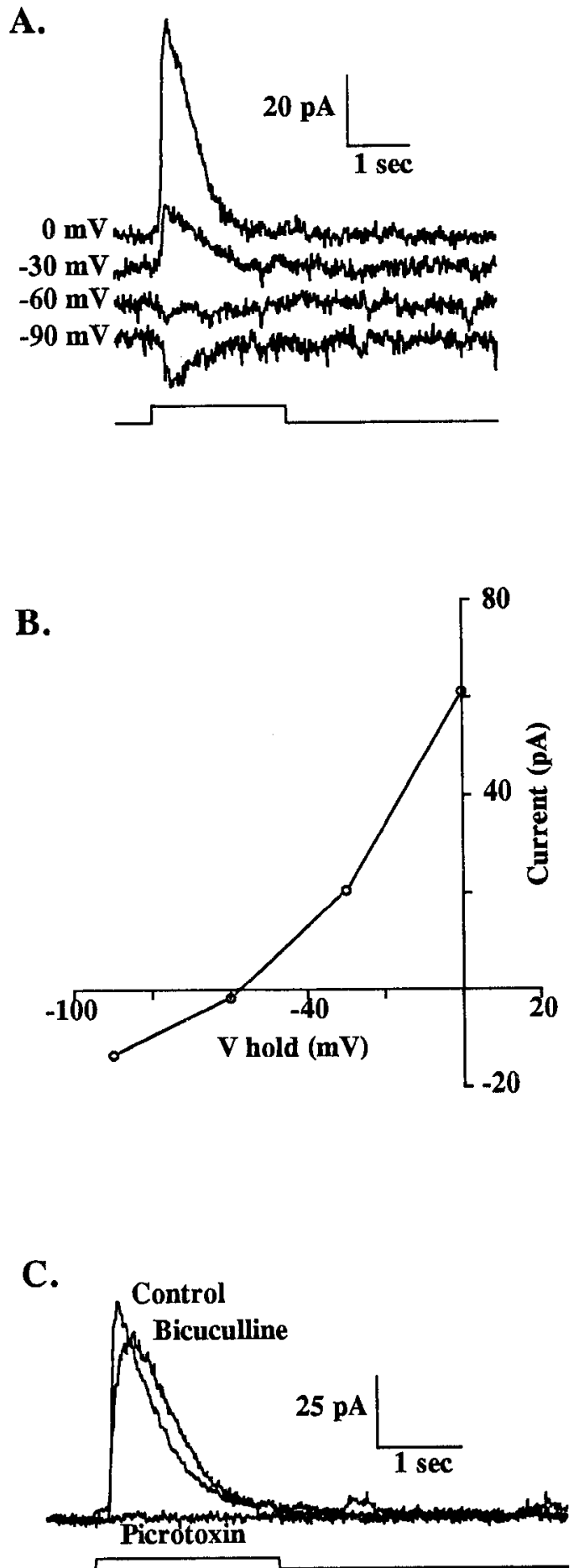

Figure 3. Light-evoked, inhibitory synaptic inputs to an ON bipolar cell. $A$, Synaptic currents recorded after the excitatory inputs ran down; the cell was held at the indicated potentials. $B$, The current-voltage relationship constructed from the peak responses measured in $A$. The responses reverse polarity near $-60 \mathrm{mV}$, which was near the calculated $E_{\mathrm{C}}(-61 \mathrm{mV})$ for this experiment. $C$, Pharmacology of light-evoked inhibitory synaptic inputs. The cell was held at $0 \mathrm{mV}$ and the calculated $E_{\mathrm{C}]}$ was $-61 \mathrm{mV}$. Picrotoxin reduced the amplitude of responses in a reversible manner. Bicuculline was relatively ineffective in reducing the amplitude of the response. The control light response is the average of pre- and postdrug responses. The recording clectrode was filled with the $\mathrm{CsSO}_{4} / \mathrm{CsCl}$ intracellular solution. inputs to an OFF bipolar cell is shown in Figure 2. The peak amplitudes of the inhibitory synaptic inputs were measured when the cell was held at the reversal potential for the excitatory components of the response $(0 \mathrm{mV})$. The timing of the drug applications is indicated by the solid lines above the peak currents in this and all subsequent figures. ON inhibitory responses are indicated by the open triangles and OFF inhibitory responses are indicated by the solid triangles. Figure $2 A$ shows that picrotoxin reversibly reduced the amplitudes of both the $O N$ and the OFF inhibitory currents. The effect of picrotoxin on the waveform of the inhibitory currents is shown in Figure $2 B$. Both the ON and OFF inhibitory components of the light response were almost completely suppressed by $100 \mu \mathrm{M}$ picrotoxin. Upon washout of picrotoxin, the amplitudes of both the ON and OFF components of the light response were larger than the predrug control responses.

Figure $2 C$ shows that peak amplitudes of the light responses at light onset and light offset were not significantly reduced by the competitive $\mathrm{GABA}_{\mathrm{A}}$ receptor antagonist bicuculline, or the competitive glycine receptor antagonist strychnine. The effects of strychnine and bicuculline on the light-elicited synaptic currents are shown in Figure $2 D$. The control current is the mean of currents labeled " $C$ " in Figure $2 C$. The current recorded in the presence of bicuculline (labeled " $\mathrm{B}$ " in Fig. 2C) was indistinguishable from the control current. However, the current recorded in the presence of strychnine (labeled " $\mathrm{S}$ " in Fig. 2C) was slightly smaller than the control response. Strychnine did not reduce the amplitudes of the light responses in 11 of 15 cells tested. However, in three cells strychnine $(0.5-2 \mu \mathrm{M})$ blocked the inhibitory synaptic input, and in a fourth cell strychnine (1 $\mu \mathbf{M})$ reduced the amplitude of the response by half. We did not investigate the effects of strychnine further, but focused on the GABA-mediated processes in the bipolar cells.

Figure 3 shows an example of the light-evoked inhibitory synaptic input recorded from an ON bipolar cell. Photoreceptormediated excitatory inputs to the $\mathrm{ON}$ bipolar cell were lost due to rundown during the whole-cell recording (Nawy and Jahr, 1990b; Lasansky, 1992). A series of light-evoked currents recorded when the cell was held at the indicated potentials is shown in Figure $3 \mathrm{~A}$. This current reversed polarity near -60 $\mathrm{mV}$. The calculated chloride equilibrium potential was -61 $\mathrm{mV}$. In some ON bipolar cells there was also an inhibitory synaptic input at the offset of the light stimulus that reversed near $-60 \mathrm{mV}$. We measured the peak amplitudes of the responses to construct the current-voltage curve shown in Figure $3 B$. The slope of the curve was roughly linear, indicating that the channels mediating this response were not significantly voltage dependent over this range of potentials. Inhibitory lightevoked currents with similar properties were reported by Lasansky (1992).

The pharmacological properties of the inhibitory synaptic input to an $\mathrm{ON}$ bipolar cell are illustrated in Figure $3 C$. The cell was voltage clamped to $0 \mathrm{mV}$, the reversal potential for the excitatory input. The inhibitory synaptic current was almost completely blocked when $100 \mu \mathrm{M}$ picrotoxin was added to the bathing medium. In contrast, $100 \mu \mathrm{M}$ bicuculline was relatively ineffective in reducing the amplitude of the inhibitory response. Bicuculline reduced the response only slightly and slowed the falling phase of the current. The control current response is the mean of predrug controls and recovery responses. In 14 of 14 bipolar cells, picrotoxin reduced the amplitude of the lightevoked inhibitory currents at both light onset and light offset. 


\section{Bipolar Cell Barium Currents}
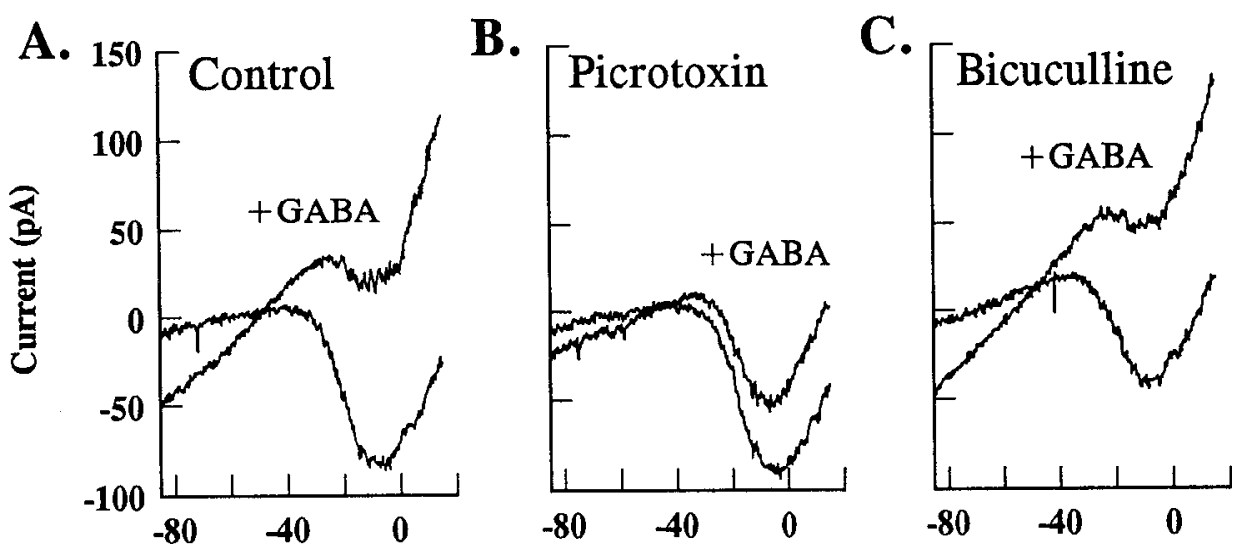

Figure 4. GABA effects on the measured chloride and voltage-gated harium currents in a bipolar cell. $A$, The current-voltage relations obtained from a voltage ramp from -85 to $15 \mathrm{mV}$ in the presence and absence of $250 \mu \mathrm{M}$ GABA in the bath. $B$, Similar paradigm as in $A$, except that $100 \mu \mathrm{M}$ picroloxin was present in the bath. Picrotoxin reduced the GABA current and increased the voltage-gated barium current. $C$, The current-voltage relations obtained from the voltage ramp when $100 \mu \mathrm{M}$ bicuculline was present in the bath. Bicuculline did not reduce the GABA current and the barium current was not increased. $D-F$, The GABA and leak currents were subtracted from the total currents (in $A-C$, respectively) to yield the voltage-gated barium currents (see Results). The GABA currents reversed between -40 and $-50 \mathrm{mV}$. The calculated reversal for the GABA current using the Goldman-Hodgkin-Katz equation was $-41 \mathrm{mV}$ assuming a $P_{\mathrm{Cl}}$ $P_{\mathrm{F}}$ of 0.02 (Hille, 1992). Intracellular solution contained $70.5 \mathrm{~mm} \mathrm{CsF}$ and $20 \mathrm{mM} \mathrm{CsCl}$ instead of the standard 90.5 $\mathrm{mm}$ CsF. Currents were not leak sub-

Voltage (mV)

In five of five bipolar cells, the inhibitory light responses were not reduced by bicuculline, but were blocked by picrotoxin.

$G A B A$ elicits a chloride current, but reduces calcium currents in bipolar cells

Many studies have suggested that GABAergic amacrine cells may reduce the release of transmitter from bipolar cell terminals (Tachibana and Kaneko, 1987; Chun and Wassle, 1989; Pourcho and Owczarzak, 1989; Heidelberger and Matthews, 1991). We investigated the interactions between the GABA-gated chloride current and the voltage-gated calcium current in bipolar terminals thought to underlie transmitter release. Barium chloride was used in place of calcium chloride to maximize the amplitude of the current through the voltage-gated calcium channels.

Figure 4 shows the effects of the bath application of GABA $(250 \mu \mathrm{M})$ on the voltage-gated barium currents in a bipolar cell. This cell was most likely an OFF bipolar cell because its processes ramificd in the outer half of the inner plexiform layer. When the membrane potential was ramped from $-85 \mathrm{mV}$ to $15 \mathrm{mV}$, at $0.21 \mathrm{mV} / \mathrm{msec}$, an inward current was elicited at potentials positive to $-45 \mathrm{mV}$ (Fig. $4 A$ ). GABA elicited an increased conductance in the bipolar cell, generating a current that reversed near $-45 \mathrm{mV}$ (the calculated reversal potential was $-40 \mathrm{mV}$ ). In the presence of GABA, the ramp now elicited a reduced barium current, as shown in Figure $4 A$. Picrotoxin $(100 \mu \mathrm{M})$ reduced the GABA-elicited current and reversed the GABA suppression of the inward barium current (Fig. 4B). Bicuculline $(100 \mu \mathrm{M})$ was not very effective in relieving the GABA suppression (Fig. 4C). Both the GABA-elicited and voltagegated barium currents were not significantly affected by bicuculline. The barium current in the presence of bicuculline remained outward (with respect to $0 \mathrm{pA}$ ). In nine of nine bipolar cells, picrotoxin reversed the GABA suppression of barium currents, but bicuculline was ineffective in reversing the GABA suppression in seven out of seven bipolar cells. No differences were seen between stained bipolar cells with ON $(n=5)$ or OFF $(n=4)$ morphologies.

The effects of the GABA antagonists on the barium current can be seen more clearly when the GABA and leak currents were subtracted, as shown in Figure $4 D-F$. The slope of a leastsquares fit of the linear current between -85 and $-55 \mathrm{mV}$ was used to determine the conductance over this voltage range. No obvious voltage-gated channels were activated over this voltage range. This conductance was then used to construct a linear offset current for the entire range of ramp voltages. This offset current was then subtracted from the raw currents. Figure $4 D$ $F$ shows the result of subtracting this current. GABA had two apparent effects on the barium current (Fig. $4 D$ ). First, it reduced the amplitude of the barium current at all measured holding 


\section{Bipolar Cell Barium Currents}

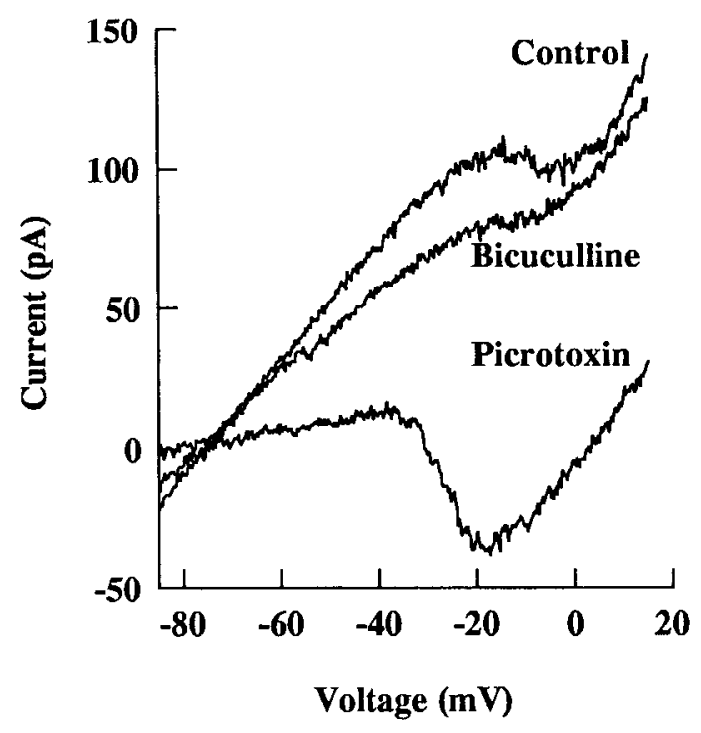

Figure 5. Bipolar cell calcium currents are tonically inhibited by GABAergic synaptic inputs. The current-voltage relations were obtained from a voltage ramp from -85 to $15 \mathrm{mV}$. The control trace was obtained with no antagonists present in the bath. Hints of a voltage-gated barium current are apparent in the control trace, but it was not a net inward current. When picrotoxin was added to the bath, the slope of the $I-V$ relation was decreased and an inward voltage-gated barium current was enhanced. Bicuculline did not significantly decrease the slope of the $I-$ $V$ relation and it did not increase the voltage-gated barium current. Currents are raw membrane currents; leak or capacitive currents were not subtracted. The CsF intracellular solution was used. Using the Gold man-Hodgkin-Katz equation and assuming a $P_{\mathrm{Cl}} / P_{\mathrm{F}}$ of 0.02 (Hille, 1992), the calculated reversal for the GABA response was $-73 \mathrm{mV}$.

potentials. Second, it shifted the current-voltage curve to more positive voltages. Picrotoxin reversed both of the GABA effects (Fig. $4 E$ ), but bicuculline was ineffective in reversing the GABA effects (Fig. $4 F$ ).

\section{Some bipolar cells have high ambient levels of GABA input}

Two bipolar cells were found to have large resting conductances, even at negative potentials where voltage-gated currents were not activated. Figure 5 shows an example of a cell with processes that ramified in the outer half of the inner plexiform layer, which received strong GABA-mediated synaptic input. The ramp voltage stimulus failed to evoke a net inward current. When 100 $\mu \mathrm{M}$ picrotoxin was added to the bath, the tonic synaptic input was blocked, revealing a net inward barium current. The picrotoxin-sensitive input reversed polarity near $-75 \mathrm{mV}$. The calculated reversal for the inhibitory input was $-73 \mathrm{mV}$. The tonic synaptic input was reduced slightly by $100 \mu \mathrm{M}$ bicuculline, but the voltage ramp stimulus still failed to evoke a net inward current. These results suggest that some bipolar cells receive strong tonic GABA-mediated synaptic inputs and this input is acting at bicuculline-insensitive GABA receptors.

\section{$G A B A$ reduces transmission to amacrine and ganglion cells}

To test if GABA could modulate transmitter release from bipolar terminals, we bioassayed bipolar transmitter release by measuring the excitatory inputs to amacrine and ganglion cells. Figure 6 shows the effects of GABA on excitatory transmission to a ganglion cell. This cell was probably an ON-OFF cell be- cause it had processes that ramified in the middle of the inner plexiform layer. The excitatory inputs were isolated by voltage clamping the cell to $-60 \mathrm{mV}$, the reversal potential for chloride. EPSCs in ganglion and amacrine cells were elicited by puffs of potassium at the bipolar dendrites. Figure $6 A$ shows that GABA $(250 \mu \mathrm{M})$ completely and reversibly suppressed potassium puffelicited EPSCs. Picrotoxin $(100 \mu \mathrm{M})$ blocked the GABA suppression of the EPSCs, but bicuculline $(100 \mu \mathrm{M})$ was completely ineffective in blocking the GABA suppression. A subsequent application of picrotoxin blocked the GABA suppression of the EPSCs again. Excitatory synaptic current responses recorded in the presence and absence of GABA are shown in Figure $6 B$. The inward current was completely suppressed by GABA and recovery occurred upon the washout of GABA. Figure $6 C$ shows that picrotoxin prevented the GABA suppression of the EPSCs, while Figure $6 D$ shows that bicuculline did not block the suppressive effects of GABA. In the presence of $100 \mu \mathrm{M}$ bicuculline, the EPSC was still completely suppressed by GABA, but recovered upon washout of GABA and bicuculline. These data indicate that the GABA receptors responsible for the suppression of synaptic transmission to these ganglion cells are primarily $\mathrm{GABA}_{C}$ receptors. Similar results were seen in six additional ganglion cells and two amacrine cells. The potent $\mathrm{GABA}_{\mathrm{A}}$ receptor antagonist SR95531 was also ineffective in reversing the GABA suppression of the EPSCs in ganglion cells. In three ganglion cells where picrotoxin did reverse the GABA suppression, $5 \mu \mathrm{M}$ SR95531 did not reverse the GABA suppression of the EPSCs. However, in three ganglion cells, bicuculline (40\% of control) or SR95531 (50 and 30\% of control) partially reversed the GABA suppression. The partial reversal of the GABA suppression by bicuculline suggests that on some bipolar terminals, $\mathrm{GABA}_{\mathrm{A}}$ receptors also modulate transmitter release. Since both bicuculline and SR 95531 potently blocked the shunting effects of puffed GABA on ganglion cells (Lukasiewicz et al., 1994), the suppression of the excitatory synaptic input in ganglion cells, in the presence of the competitive $\mathrm{GABA}_{\mathrm{A}}$ antagonists, was most likely mediated presynaptically at the bipolar cell.

Tonic inhibition of EPSCS is blocked by picrotoxin but not bicuculline or SR9553I

Bipolar cell transmitter release was tonically inhibited in many experiments, presumably from sustained synaptic input from GABAergic amacrine cells. Figure 6 shows an example of tonic inhibition of bipolar transmitter release by a GABAergic synaptic input. The amplitudes of the excitatory inputs were increased when picrotoxin was added to the bath. This suggests that picrotoxin blocked a tonic inhibitory synaptic input that normally reduced bipolar cell transmitter relcase in this cxperiment. The amplitudes of the excitatory inputs were not enhanced when bicuculline (or SR95531) was present in the bath, indicating that a conventional $\mathrm{GABA}_{\mathrm{A}}$ receptor did not play a major role in inhibiting transmitter release, while further suggesting that $\mathrm{GABA}_{C}$ receptors were involved.

\section{$C A C A$ and TACA suppress excitatory transmission to ganglion} cells

We tested the abilities of the isomeric GABA agonists CACA and TACA to suppress synaptic transmission between bipolar and ganglion cells. CACA has been shown to modulate calcium influx in goldfish bipolar cells (Matthews et al., 1991). In addition, CACA also elicited a chloride current in tiger salamander 


\section{Ganglion Cell}
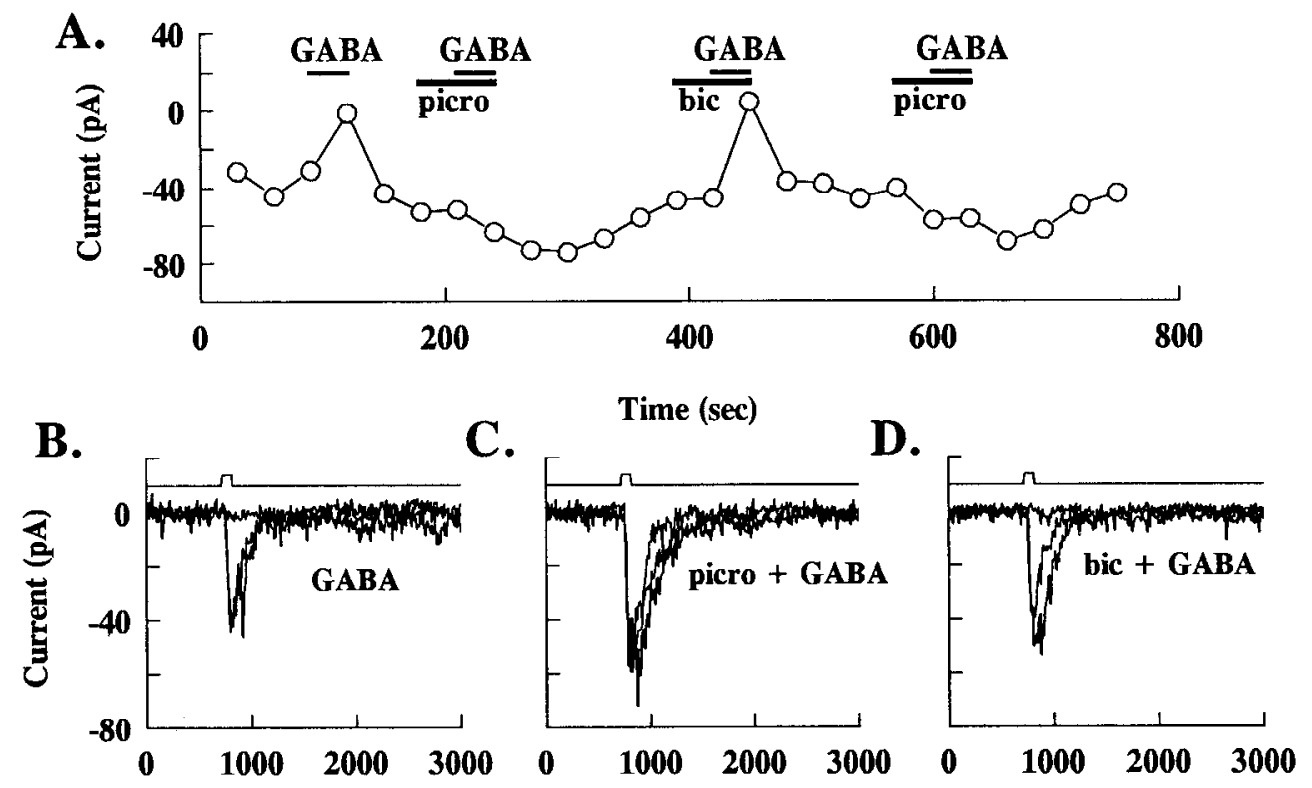

Time (msec)

Figure 6. GABA blocks synaptic transmission to a ganglion cell with ON-OFF morphology. A, Pcak current amplitudes of cxcitatory synaptic inputs are plotted versus time. EPSCs were elicited by depolarizing bipolar cells with puffs of potassium in the outer plexiform layer. Excitatory inputs were isolated by holding the cell at $-60 \mathrm{mV}$, the reversal potential for its inhibitory inputs. Bath application of $250 \mu \mathrm{M}$ GABA completely and reversibly blocked the excitatory synaptic input. In the presence of $100 \mu \mathrm{M}$ picrotoxin the excitatory input was not affected by the GABA application. However, GABA did block the excitatory input in the presence of $100 \mu \mathrm{M}$ bicuculline. $B$, Individual records of the excitatory input before, during (the flat trace), and after GABA application. GABA completely and reversibly depressed the excitatory input. $C$, Synaptic currents recorded in the presence of picrotoxin. The GABA suppression of the excitatory input was blocked by picrotoxin. $D$, Synaptic currents recorded in the presence of bicuculline. The flat current trace indicates that the GABA suppression of the excitatory input was not blocked by bicuculline. For this, and the next two figures, the intracellular solution contained $85 \mathrm{~mm} \mathrm{CsF}$ and $5 \mathrm{~mm} \mathrm{CsCl}$ instead of the standard $90 \mathrm{~mm}$ CsF. Using the Goldman-Hodgkin-Katz equation and assuming a $P_{\mathrm{Cl}} / P_{\mathrm{F}}$ of 0.02 (Hille, 1992), the calculated reversal for the GABA response was $-59 \mathrm{mV}$.

bipolar cells that was insensitive to bicuculline or SR95531 (Lukasiewicz et al., 1994). Figure 7 shows the effect of $250 \mu \mathrm{M}$ CACA on excitatory synaptic transmission to a ganglion cell. The peak amplitudes of the ganglion cell EPSCs, evoked by potassium puffs in the outer plexiform layer, are plotted as a function of time in Figure $7 A$. The ganglion cell was voltage clamped to the chloride equilibrium potential, $-60 \mathrm{mV}$, to isolate the EPSCs. The EPSCs were completely, and reversibly, suppressed by bath-applied CACA. This CACA-mediated suppression of the EPSCs was not reduced by $100 \mu \mathrm{M}$ bicuculline, but was completely blocked by $100 \mu \mathrm{M}$ picrotoxin. The extent of the CACA-mediated LPSC suppression is shown more clearly in Figure 7, $B$ and $C$. An equivalent amount of CACA-mediated suppression was seen in either the absence or presence of hicuculline. This indicates that $\mathrm{GABA}_{\mathrm{A}}$ receptors play only a minor role in modulating transmitter release from bipolar cells that drive this ganglion cell. Figure $7 D$ shows that the amplitude of the EPSC was not reduced when CACA was applied in the presence of picrotoxin. Similar results were found in six additional ganglion cells. The blockade of the CACA suppression of the EPSC by picrotoxin indicates that a presynaptic GABA, receptor modulates transmitter release from the bipolar cells that drive these ganglion cells. However, in two ganglion cells, bicuculline partially reversed the CACA suppression of the EPSCs (to $40 \%$ and $30 \%$ of control). This suggests that both $\mathrm{GABA}_{\mathrm{A}}$ and $\mathrm{GABA}_{C}$ receptors modulate transmitter release from the bipolar cells that drive these two ganglion cells.
Heidelberger and Matthews (1991) reported that in the presence of picrotoxin, GABA, but not muscimol, suppressed calcium currents in goldfish bipolar terminals. This indicates that in goldfish bipolar terminals, GABA may modulate transmitter release by a mechanism that does not involve either $\mathrm{GABA}_{A}$ or $\mathrm{GABA}_{C}$ receptors. The absence of any CACA suppression in the presence of picrotoxin argues against CACA directly modulating calcium channels on the tiger salamander bipolar terminals. Figure $6, A$ and $C$, shows that GABA did not suppress EPSC's when it was applied in the presence of picrotoxin. In the presence of picrotoxin, the amplitudes of the EPSCs were larger than the control currents. This enhancement of the EPSCs in the presence of GABA and picrotoxin is inconsistent with GABA acting directly on calcium channels in bipolar terminals.

Figure 8 shows that TACA also effectively suppressed excitatory transmission between bipolar and ganglion cells. EPSCs were isolated by holding the ganglion cell at $-60 \mathrm{mV}$, the calculated chloride reversal potential. This ganglion cell was most likely an ON-OFF cell because its processes stratified in sublaminae A and B. The TACA $(250 \mu \mathrm{M})$ suppression of the EPSCs was not reversed by $5 \mu \mathrm{M}$ SR95531, as shown in Figure 8, $A$ and $B$. The lack of SR95531 antagonism in this experiment indicates that $\mathrm{GABA}_{\mathrm{A}}$ receptors do not significantly modulate transmitter release from the bipolar terminal. However, picrotoxin $(100 \mu \mathrm{M})$ completely reversed the TACA $(250 \mu \mathrm{M})$ suppression of the ganglion cell EPSCs. The antagonism by picrotoxin, but not SR95531 (or bicuculline), suggests that TACA, 
Figure 7. CACA blocks synaptic transmission to a ganglion cell. $A$, Peak current amplitudes of excitatory synaptic inputs to a ganglion cell are plotted as a function of time. EPSCs were elicited by depolarizing bipolar cells with puffs of potassium in the outer plexiform layer. Excitatory inputs were isolated by holding the cell at $-60 \mathrm{mV}$, the reversal potential for its inhibitory inputs. Bath application of $250 \mu \mathrm{M}$ CACA completely and reversibly blocked the excitatory synaptic input. CACA also blocked the excitatory input in the presence of $100 \mu \mathrm{M}$ bicuculline. In the presence of $100 \mu \mathrm{M}$ picrotoxin the excitatory input was not affected by the GABA application. $B$, Individual records of the excitatory input before and during CACA application. The flat trace shows that CACA completely and reversibly depressed the excitatory input. $C$, Synaptic currents recorded in the presence of bicuculline. The CACA suppression of the excitatory input was not blocked by bicuculline as indicated by the flat current trace. $D$, Synaptic currents recorded in the presence of picrotoxin. The CACA suppression of the excitatory input is blocked by picrotoxin.

\section{Ganglion Cell}
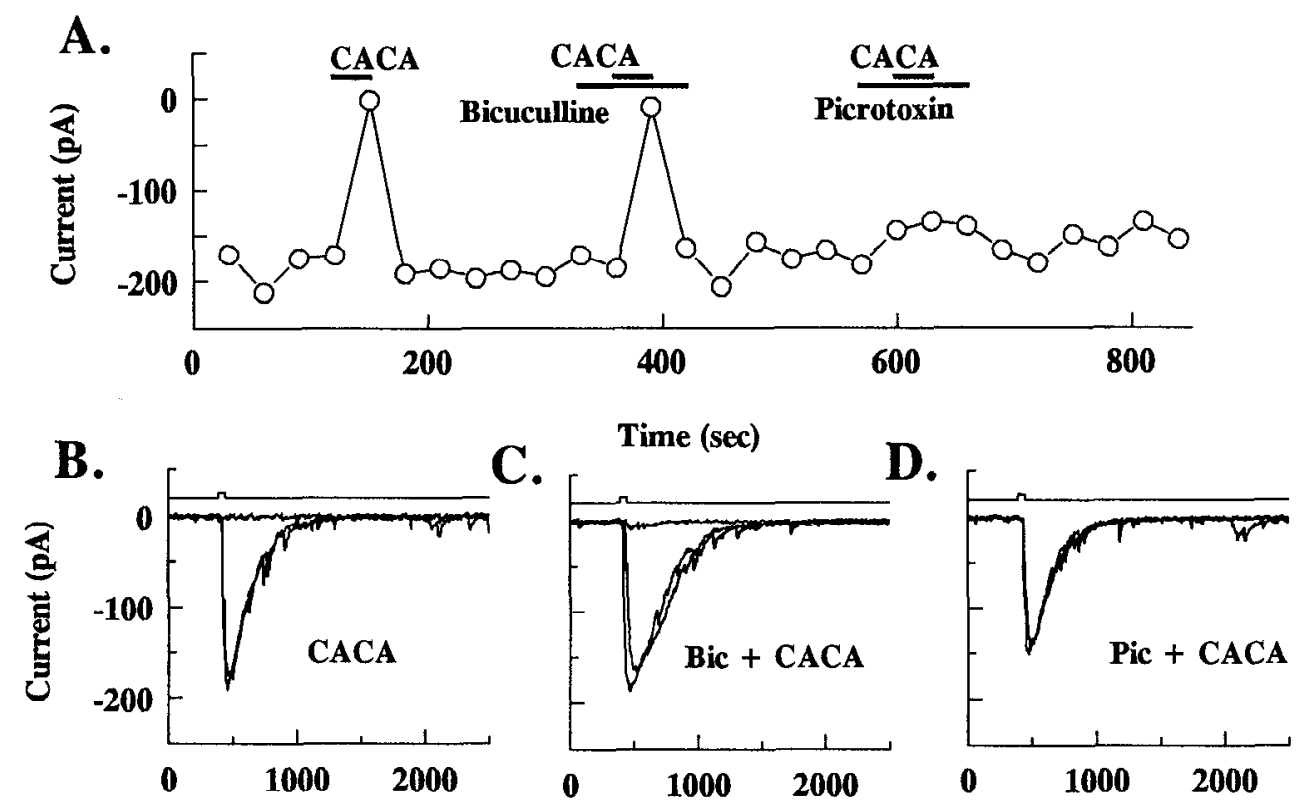

like CACA and GABA, was most likely acting at $\mathrm{GABA}_{C}$ receptors on the bipolar terminals. Bicuculline and SR95531 effectively antagonized the effects of TACA and GABA at GABA receptors on salamander ganglion cells (Lukasiewicz et al., 1994). The TACA suppression of the EPSCs was completely reversed by picrotoxin in six of six ganglion cells. In four of six ganglion cells, the bicuculline did not affect the TACA suppression of the EPSCs. However, in two ganglion cells, bicuculline partially reversed the TACA suppression (to $70 \%$ and $50 \%$ of control). This further indicates that, in some cases, $\mathrm{GABA}_{\mathrm{A}}$ receptors may also play a role in modulating bipolar transmitter release.

\section{Discussion}

GABA inhibition of transmitter release

We have attempted to define the mechanisms by which GABA modulates transmitter release at the bipolar terminal. We have shown that the light-elicited inhibitory inputs to bipolar terminals have a similar pharmacology to that reported for GABA receptors on bipolar terminals (Feigenspan et al., 1993; Lukasiewicz et al., 1994). This suggests that the light-elicited inputs, presumed to come from amacrine cells, can act at $\mathrm{GABA}_{c}$ receptors. Although the feedback pathway from horizontal cells to cones is thought to predominate in most lower vertebrate retinas (Wu, 1992), we cannot rule out that some feedforward input exists from horizontal cells to bipolar cells (Yang and $\mathrm{Wu}$, 1991; Hare and Owen, 1992). However, the dominance of GABA sensitivity at the bipolar terminals suggests that most of the GABAergic synaptic input is at the terminal (Tachibana and Kancko, 1987; Karschin and Wasslc, 1990; Heidclberger and Matthews, 1991; Lukasiewicz et al., 1994).

The effects of GABA agonists on bipolar cell transmitter release were assayed by measuring the excitatory synaptic inputs to ganglion cells. GABA, CACA, and TACA all reversibly suppressed transmission from bipolar cells to ganglion cells. The GABA suppression of excitatory input to ganglion cells was blocked by picrotoxin, but in most ganglion cells not by bicuculline or SR 95531. Since GABA receptors on salamander bipolar terminals were also relatively insensitive to bicuculline and SR 95531, this suggests that the GABA suppression of EPSCs occurred presynaptically, at the bipolar cell terminals. The EPSC amplitudes were probably not reduced because of shunting by the GABA receptors on ganglion cells. The ganglion cell GABA currents were blocked by bicuculline and SR95531 (Lukasiewicz et al., 1994), indicating that they were mediated by conventional $\mathrm{GABA}_{\mathrm{A}}$ receptors. The fact that, in most cells, the EPSCs were not suppressed by bicuculline or SR95531 suggests that GABA acts presynaptically, and predominantly at $\mathrm{GABA}_{C}$ receptors, to suppress bipolar cell transmitter release.

\section{Mechanism of GABA action}

By puffing GABA at the bipolar terminal (Lukasiewicz et al., 1994), we have characterized a GABA receptor subtype, the $\mathrm{GABA}_{C}$ receptor. The properties of this GABA receptor are similar to the $\rho 1$ receptor subunit expressed in Xenopus oocytes (Polenzani et al., 1991; Shimada et al., 1992). At this receptor, GABA activation of chloride channels is blocked by picrotoxin, but not by the competitive $\mathrm{GABA}_{\mathrm{A}}$ antagonists SR95531 and bicuculline. The $\mathrm{GABA}_{\subset}$ receptor-elicited chloride current can act as a shunt in bipolar cells, decreasing the magnitude of the calcium current at the terminal. $\mathrm{GABA}_{\mathrm{A}}$ receptors, when present, can similarly shunt bipolar cell terminals (Heidelberger and Matthews, 1991). GABA activation of the chloride shunt would act as a voltage divider, attenuating depolarizations that originate in the cell body at the terminal. This mechanism would reduce transmitter release by decreasing depolarization at the terminal, leading to less activation of the voltage-gated calcium channels.

An alternative mechanism for the modulation of bipolar cell transmitter release by GABA has been suggested by Heidelberger and Matthews (1991). They showed that GABA can shift 


\section{Ganglion Cell}

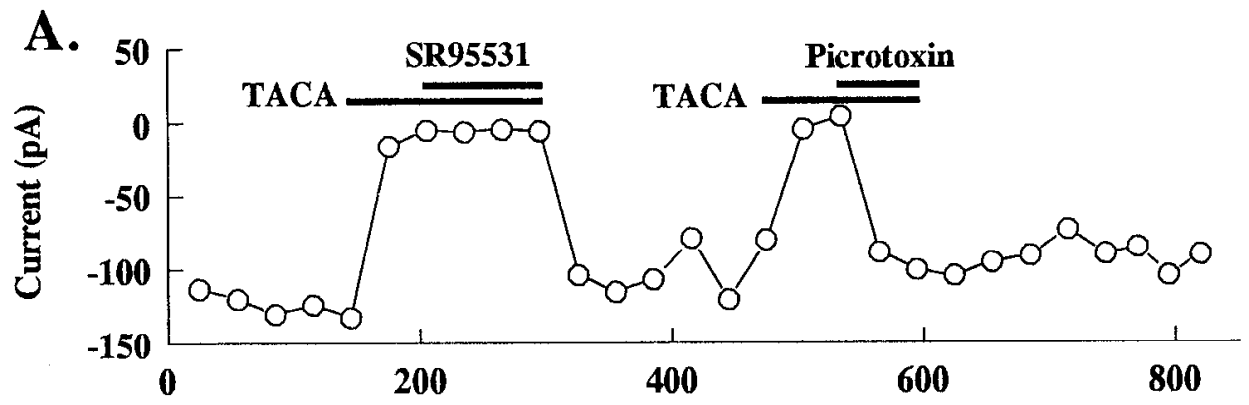

Figure 8. TACA blocks synaptic transmission to a ganglion cell. $A$, Peak current amplitudes of excitatory synaptic inputs to a Lucifer yellow-injected ganglion cell with an ON-OFF morphology are plotted versus time. EPSCs were elicited by depolarizing bipolar cells with puffs of potassium in the outer plexiform layer. Excitatory inputs were isolated by holding the cell at -60 $\mathrm{mV}$, the reversal potential for its inhibitory inputs. $A$, Bath application of 250 $\mu \mathrm{M}$ TACA completely and reversibly blocked the excitatory synaptic input. The TACA suppression of the EPSCs was reversed by $100 \mu \mathrm{M}$ picrotoxin, but not $5 \mu \mathrm{M}$ SR95531. $B$, Individual records of the excitatory input before and during TACA application. The two flat traces show that TACA suppressed the EPSCs in both the absence and presence of SR95531. C, TACA suppression of the EPSC (flat trace) was reversed by Time (msec)

Time (msec) picrotoxin.

the current-voltage relationship for calcium channels in goldfish bipolar terminals by a $\mathrm{GABA}_{\mathrm{A}}$ and $\mathrm{GABA}_{\mathrm{B}}$ receptor-independent mechanism. The positive shift in the calcium currentvoltage relation would decrease calcium influx and thereby reduce transmitter release. This effect of GABA on calcium currents was not blocked by picrotoxin and could not be mimicked by the $\mathrm{GABA}_{\mathrm{A}}$ agonist muscimol. Thus, this may be a non$\mathrm{GABA}_{C}$ mechanism, as well. The mechanism of GABA action at the bipolar terminal in salamander seems to be different from that in goldfish. We found that picrotoxin reversed the GABA suppression of synaptic transmission and also the GABA suppression of the bipolar barium currents. A direct modulation of calcium channels by GABA should still be apparent in the presence of picrotoxin (Maguire et al., 1989b; Heidelberger and Matthews, 1991). The lack of any suppression of transmission by GABA, CACA, or TACA in the presence of picrotoxin suggests that these agonists do not directly modulate calcium channels in salamander bipolar terminals. Our results indicate that transmission from bipolar cells to ganglion cells is primarily modulated by bicuculline-insensitive $\mathrm{GABA}_{C}$ receptors. Since in some experiments bicuculline partially reversed the GABA suppression of transmitter release, it was apparent that both $\mathrm{GABA}_{\mathrm{A}}$ and $\mathrm{GABA}_{\mathrm{C}}$ receptors could modulate bipolar transmittcr relcasc. $\mathrm{GABA}_{\mathrm{B}}$ (Maguire et al., 1989b) or non-GABA (Heidelberger and Matthews, 1991) receptors that act directly on calcium channels did not appear to play a major role in modulating transmitter release in our experiments.

What is the physiological role of the GABA inpul to bipolar cell $G A B A$ receptors?

Whereas it was apparent from our results that $\mathrm{GABA}_{C}$, and in some cases $\mathrm{GABA}_{\mathrm{A}}$ receptors, can modulate transmitter release from the bipolar cells, the question of the physiological roles of this modulation still remains. Figure 5 shows that some bipolar cell terminals receive a tonic GABA inhibition that reduces the amplitude of the measured barium currents. In these cases, where there exists a high level of GABA input to the terminal, picrotoxin permits greater excitatory transmission to amacrine and ganglion cells (see Fig. 6). The GABAergic input to bipolar terminals may play a number of roles that are similar to the horizontal cell GABAergic feedback to cone terminals (Werblin, 1991; Wu, 1992). The GABAergic amacrine cell to bipolar terminal synapse forms a negative feedback circuit; a portion of the bipolar output is fed back from GABAergic amacrine cells to the bipolar terminal. This feedback to the bipolar terminal may act to improve the signal-to-noise ratio, increase the band width, and enhance the stability of the bipolar to ganglion cell synapse. This synapse could also mediate a component of the surround response in ganglion cells. A component of the steady surround input to mudpuppy ganglion cells may be mediated by amacrine cells (Belgum et al., 1987). Although this surround component is probably due to direct amacrine input to the ganglion cells, presynaptic inhibition of transmitter release from bipolar terminals may also mediate a component of the steady surround input to ganglion cells. Just as horizontal cell inputs control the gain of the cone to bipolar synapse (Werblin, 1974), the GABAergic amacrine input may act to control the gain of the bipolar to ganglion cell synapse. The GABAergic amacrine synapse to bipolar terminals provides for a potential gain control site for the bipolar to ganglion cell synapse. The GABAergic amacrine synapse described here is probably not the site of truncation of bipolar signals that leads to transient activity in the postsynaptic amacrinc and ganglion cclls (Werblin et al., 1988). This is because the transient excitatory light responses 
recorded in third-order retinal cells were not significantly affected by picrotoxin (Belgum et al., 1984; Werblin et al., 1988; Maguire et al., 1989b). This suggests that $\mathrm{GABA}_{c}$ or $\mathrm{GABA}_{\mathrm{A}}$ receptors do not play a major role in the formation of transient responses in the inner retina.

\section{Pre- and postsynaptic $G A B A$ receptors in the inner retina}

Ultrastructural evidence indicates that bipolar cells and ganglion cells receive synaptic input from the same class of GABAergic amacrine cells in goldfish (Muller and Marc, 1990). This occurs for both the ON and the OFF pathways. Similar classes of amacrine cells that make both feedback and feedforward synaptic contacts in the tiger salamander inner plexiform layer may do so at pharmacologically distinct $G A B A$ receptors: $G_{A B A}$ and $\mathrm{GABA}_{\mathrm{A}}$ receptors on bipolar cells and $\mathrm{GABA}_{\mathrm{A}}$ receptors on ganglion cells.

Additional support for two populations of GABA receptors in the inner plexiform layer comes from the work of Hughes et al. 1991). Immunohistochemical evidence from the cat inner retina shows that the GABA receptors on bipolar cells are distinct from those on ganglion cells (Hughes et al., 1991). Cat rod bipolar cells were not labeled by a $\mathrm{GABA}_{\mathrm{A}}$ receptor antibody, even though there is good evidence that these cells receive GABAergic input (Chun and Wassle, 1989; Pourcho and Owczarzak, 1989). This antibody did, however, label both amacrine and ganglion cells in the cat retina. One explanation for these results is that this antibody recognizes a subset of the $\mathrm{GABA}_{\mathrm{A}}$ receptors that may be different on bipolar and third-order retinal neurons. Alternatively, the GABA receptor on cat rod bipolar cells may not be a $G A B A_{A}$ receptor at all, but a $G A B A_{C}$ receptor similar to that reported here in tiger salamander bipolar cells and in rat bipolar cells (Feigenspan et al., 1993). In cat, the GABA rcceptors that mediatcd feedback to bipolar cells were antigenically different from the GABA receptors that mediated feedforward to amacrine and ganglion cells.

\section{Summary}

GABA, presumably released from amacrine cells, acts at the bipolar terminal to increase chloride conductances in bipolar cells. We have shown (Lukasiewicz et al., 1994) that most of the GABA receptors on both $O N$ and OFF bipolar cell terminals were of the $\mathrm{GABA}_{c}$ subtype. These receptors were resistant to blockade by bicuculline or SR95531, but were sensitive to picrotoxin. In contrast, all GABA receptors on ganglion cells were apparently sensitive to bicuculline, indicating that they were of the $\mathrm{GABA}_{\mathrm{A}}$ subtype. Here, we show that the light-elicited inhibitory inputs to $O N$ and OFF bipolar cells were also mediated predominantly by $\mathrm{GABA}_{\mathrm{C}}$ receptors (Figs. 2,3 ). This is consistent with light-elicited GAB $\mathrm{Gergic}$ modulation of transmitter release from bipolar terminals. Our studies on the action of GABA on calcium channel function in the bipolar terminal and on synaptic transmission between bipolar and ganglion cells support this notion. We found that GABA reduced the barium currents at the bipolar terminals by acting at bicuculline-insensitive $\mathrm{GABA}_{C}$ receptors (Figs. 4, 5). By recording EPSCs from ganglion and amacrine cells, we were able to bioassay the release of transmitter from bipolar cells (Figs. 6-8). We found that the activation of $\mathrm{GABA}_{C}$ receptors, and to a lesser extent $\mathrm{GABA}_{\mathrm{A}}$ receptors, resulted in a reduction of EPSC amplitudes. These data provide further support that $\mathrm{GABA}_{C}$ receptors can modulate bipolar cell transmitter release. We also demonstrated that transmitter release from bipolar cell terminals can be reduced by a $\mathrm{GABA}_{C}$ receptor-elicited chloride current that may act as a shunt. This would cause depolarizing signals, measured at the soma, to be attenuated at the terminal, decreasing the magnitude of the calcium current at the terminal. Our findings are consistent with anatomical evidence that GABAergic amacrine cells feed back to bipolar cells and feed forward to ganglion cells (Muller and Marc, 1990). Based on our results, we conclude that $\mathrm{GABA}_{\mathrm{C}}$ and $\mathrm{GABA}_{\mathrm{A}}$ receptors mediate the feedback signal and $\mathrm{GABA}_{\mathrm{A}}$ receptors mediate the feedforward signal. Further work is nccessary to distinguish the physiological roles of GA$\mathrm{BA}_{\mathrm{C}}$ and $\mathrm{GABA}_{\mathrm{A}}$ receptor-mediated feedback on to bipolar cells.

\section{References}

Belgum JH, Dvorak DR, McReynolds JS (1984) Strychnine blocks transient but not sustained inhibition in mudpuppy retinal ganglion cells. J Physiol (Lond) 354:273-286.

Belgum JH, Dvorak DR, McReynolds JS, Miyachi E-I (1987) Pushpull effect of surround illumination on excitatory and inhibitory inputs to mudpuppy retinal ganglion cells. J Physiol (Lond) 388:233-243.

Chun MH, Wassle H (1989) GABA-like immunoreactivity in the cat retina: electron microscopy. J Comp Neurol 279:55-67.

Cutting GR, Lu L, O'Hara BF, Kasch LM, Montrose-Rafizadeh C, Donovan DM, Shimada S, Antonarkakis SE, Guggino WB, Uhl GR, Kazazian HH (1991) Cloning of the $\gamma$-aminobutyric acid (GABA) $\rho 1$ cDNA: a GABA receptor subunit highly expressed in the retina. Proc Natl Acad Sci USA 88:2673-2677.

Feigenspan A, Wässle H, Bormann J (1993) Pharmacology of GABA receptor $\mathrm{Cl}^{-}$channels in rat retinal bipolar cells. Nature 361:159162.

Hamill OP, Marty A, Neher E, Sakmann B, Sigworth FJ (1981) Improved patch-clamp techniques for high resolution current recording from cells and cell-free membrane patches. Pfluegers Arch 391:85100.

Hare WA, Owen WG (1992) Effects of 2-amino-4-phosphonobutyric acid on cells in the distal layers of the tiger salamander's retina. $J$ Physiol (Lond) 445:741-757.

Heidelberger R, Matthews G (1991) Inhibition of calcium influx and calcium current by $\gamma$-aminobutyric acid in single synaptic terminals. Proc Natl Acad Sci USA 88:7135-7139.

Heidelberger R, Matthews G (1992) Calcium influx and calcium current in single synaptic terminals of goldfish retinal bipolar ncurons. J Physiol (Lond) 447:235-256.

Hille B (1992) Ionic channels of excitable membranes. Sunderland, MA: Sinauer.

Hughes TE, Grunert U, Karten HJ (1991) GABA receptors in the retina of the cat: an immunohistochemical study of wholemounts, sections, and dissociated cells. Vis Neurosci 6:229-238.

Hurd LD II, Eldred WD (1989) Localization of GABA- and GADlike immunoreactivity in the turtle retina. Vis Neurosci 3:9-20.

Johnston GAR (1986) Multiplicity of GABA receptors. In: Benzodiazepine/GABA receptors and chloride channels. Receptor biochemistry and methodology, Vol 5 (Olsen RW, Venter IC, eds), pp 57-71. New York: Liss.

Karschin A, Wassle H (1990) Voltage- and transmitter-gated currents in isolated rod bipolar cells of the rat retina. J Neurophysiol 63:860876.

Lasansky A (1992) Properties of depolarizing bipolar cell responses to central illumination in salamander retina. Brain Res 576:181-196.

Lukasiewicz PD, Werblin FS (1990) The spatial distribution of excitatory and inhibitory inputs to ganglion cells dendrites in the tiger salamander retina. J Neurosci 10:210-221.

Lukasiewicz PD, Maple BR, Werblin FS (1994) A novel GABA receptor on bipolar cell terminals in the tiger salamander retina. J Neurosci 14:1202-1212.

Maguire G, Maple B, Lukasiewicz P, Werblin F (1989a) $\gamma$-Aminobutyric acid type $B$ receptor modulation of L-type calcium current at bipolar cell terminals in the retina of the tiger salamander. Proc Natl Acad Sci USA 86:10144-10147.

Maguire G, Lukasiewicz P, Werblin F (1989b) Amacrine cell interactions underlying the response to change in the tiger salamander retina. J Neurosci 9:726-735. 
Maple BR, Werblin FS (1986) Inhibitory feedback to bipolar cells in the tiger salamander retina. Soc Neurosci Abstr 12:634.

Marc RE, Stell WK, Bok D, Lam DMK (1978) GABA-ergic pathways in the goldfish retina. J Comp Neurol 182:221-246.

Matthews G, Ayoub G, Heidelberger R (1991) Inhibition of presynaptic calcium current via $\mathrm{GABA}_{C}$ receptors. Soc Neurosci Abstr 17: 900.

Muller JF, Marc RE (1990) GABA-ergic and glycinergic pathways in the inner plexiform layer of the goldfish retina. J Comp Neurol 291: 281-304.

Muller JF, Ammermüller J, Normann RA, Kolb H (1991) Synaptic inputs to physiologically defined turtle retinal ganglion cells. Vis Neurosci 7:409-429.

Nawy S, Jahr CE (1990a) Suppression by glutamate of cGMP-activated conductance in retinal bipolar cells. Nature 346:269-271.

Nawy S, Jahr CE (1990b) Time-dependent reduction of glutamate current in retinal bipolar cells. Neurosci Lett 108:279-283.

Polenzani L, Woodward RM, Miledi R (1991) Expression of mammalian $\gamma$-aminobutyric acid receptors with distinct pharmacology in Xenopus oocytes. Proc Natl Acad Sci USA 88:4318-4322.

Pourcho RG, Owczarzak MT (1989) Distribution of GABA immunoreactivity in the cat retina: a light- and electron-microscopic study. Vis Neurosci 2:425-435.

Shimada S, Cutting G, Uhl GR (1992) $\gamma$-Aminobutyric acid A or C receptor? $\gamma$-Aminobutyric acid $\rho 1$ receptor RNA induces bicuculline-, barbiturate, and benzodiazepine-insensitive $\gamma$-aminobutyric acid responses in Xenopus oocytes. Mol Pharmacol 41:683-687.
Tachibana M, Kaneko A (1987) $\gamma$-Aminobutyric acid exerts a local inhibitory action on the axon terminal of bipolar cells: evidence for negative feedback from amacrine cells. Proc Natl Acad Sci USA 84: $3501-3505$.

Werblin FS (1974) Control of retinal sensitivity. II. Lateral interactions at the outer plexiform layer. J Gen Physiol 63:62-87.

Werblin FS (1978) Transmission along and between rods in the tiger salamander retina. J Physiol (Lond) 280:449-470.

Werblin F (1991) Synaptic connections, receptive fields, and patterns of activity in the tiger salamander retina. Invest Ophthalmol Vis Sci 32:459-483.

Werblin F, Maguire G, Lukasiewicz P, Eliasof S, Wu SM (1988) Neural interactions mediating the detection of motion in the retina of the tiger salamander. Vis Neurosci 1:317-329.

Wu SM (1992) Feedback connections and operation of the outer plexiform layer of the retina. Curr Opin Neurobiol 2:462-468.

Yang C-Y, Lukasiewicz P, Maguire G, Werblin F, Yazulla S (1991) Amacrine cells in the tiger salamander retina: morphology, physiology, and neurotransmitter identification. J Comp Neurol 311:1-14.

Yang XL, Wu SM (1991) Feedforward lateral inhibition: Input-output elation of the horizontal cell to bipolar synapse in the tiger salamander retina. Proc Natl Acad Sci USA 88:3310-3313.

Yazulla S, Studholme KM, Wu J-Y (1987) GABAergic input to the synaptic terminals of $\mathrm{mb}_{1}$ bipolar cells in the goldfish retina. Brain Res 411:400-405. 